\title{
Herbidospora sakaeratensis sp. nov., isolated from soil, and reclassification of Streptosporangium claviforme as a later synonym of Herbidospora cretacea
}

Correspondence

Vichien Kitpreechavanich fsciwck@ku.ac.th

\author{
Antika Boondaeng, ${ }^{1}$ Chanwit Suriyachadkun, ${ }^{2}$ Yuumi Ishida, ${ }^{3}$ \\ Tomohiko Tamura, ${ }^{3}$ Shinji Tokuyama ${ }^{4}$ and Vichien Kitpreechavanich ${ }^{1,5}$ \\ ${ }^{1}$ Faculty of Science, Kasetsart University, Bangkok 10900, Thailand \\ ${ }^{2}$ BIOTEC Culture Collection National Center for Genetic Engineering and Biotechnology, \\ Pathumthani 12120, Thailand \\ ${ }^{3}$ NITE Biological Resource Center (NBRC), National Institute of Technology and Evaluation, Chiba \\ 292-0818, Japan \\ ${ }^{4}$ Faculty of Agriculture, Shizuoka University, Shizuoka 422-8529, Japan \\ ${ }^{5}$ Center for Advanced Studies in Tropical Natural Resources, KU Institute for Advanced Studies, \\ Kasetsart University, Bangkok 10900, Thailand
}

\begin{abstract}
An actinomycete strain, DMKUA $205^{\top}$, was isolated from a soil sample collected from the Sakaerat Biosphere Reserve in Nakhonratchasima Province, Thailand. The novel strain produced short chains of non-motile spores on the tips of long sporophores branching from the vegetative hyphae. The morphological and chemotaxonomic properties of this new isolate corresponded to those of members of the genus Herbidospora. Furthermore, 16S rRNA gene sequence analysis showed that the strain was closely related to members of the genus Herbidospora. Phenotypic properties and DNA-DNA relatedness values differentiated the new strain from its closest phylogenetic relatives Herbidospora yilanensis $0351 \mathrm{M}-12^{\top}$ (35-54 \% DNA-DNA relatedness) and Herbidospora daliensis $0385 \mathrm{M}-1^{\top}$ (58-65\% relatedness). On the basis of phenotypic, genotypic and phylogenetic data, strain DMKUA $205^{\top}$ could be clearly distinguished from the type strains of $H$. yilanensis and $H$. daliensis. Therefore, strain DMKUA $205^{\top}$ represents a novel species, for which the name Herbidospora sakaeratensis sp. nov. is proposed. The type strain is strain DMKUA $205^{\top}$ $\left(=\right.$ BCC $11662^{\top}=$ NBRC $\left.102641^{\top}\right)$. In addition, the DNA-DNA hybridization results from this study revealed that Streptosporangium claviforme is a later synonym of Herbidospora cretacea.
\end{abstract}

The genus Herbidospora was described by Kudo et al. (1993) for actinomycete strains that produce (short) chains of spores (10-30 spores per chain) on the tip of sporophores from vegetative mycelia. This genus belongs to the family Streptosporangiaceae and currently encompasses four species with validly published names, Herbidospora cretacea and the recently described species $H$. yilanensis, $H$. daliensis and $H$. osyris. In the course of a study on the diversity of actinomycetes in Thailand, we isolated an actinomycete, strain DMKUA $205^{\mathrm{T}}$, having a similar morphology to members of the genus Herbidospora. In the present study, conducted using a polyphasic approach, strain DMKUA $205^{\mathrm{T}}$ is proposed as representing

Abbreviation: ISP, International Streptomyces project.

The GenBank/EBML/DDBJ accession number for the 16S rRNA gene sequence of strain DMKUA $205^{\top}$ is FJ199995. a novel species of the genus Herbidospora. In addition, the taxonomic position of Streptosporangium claviforme was investigated in this study because of its close phylogenetic relationship with $H$. cretacea.

Strain DMKUA $205^{\mathrm{T}}$ was isolated from a soil sample collected from the Sakaerat Biosphere Reserve in Nakhonratchasima, Thailand. The strain was isolated using a dilution plate technique on humic acid-vitamin agar (Hayakawa \& Nonomura, 1987) after incubation at $30^{\circ} \mathrm{C}$ for 21 days. The utilization of carbon sources was tested using International Streptomyces Project (ISP) medium 9 (ISP 9; Shirling \& Gottlieb, 1966) supplemented with $1 \%$ $(w / v)$ final concentration of the tested carbon sources. Utilization of nitrogen sources was examined on a basal medium containing $10 \mathrm{~g}$ glucose, $0.5 \mathrm{~g} \mathrm{MgSO}_{4} .7 \mathrm{H}_{2} \mathrm{O}$, $0.5 \mathrm{~g} \mathrm{NaCl}, 0.01 \mathrm{~g} \mathrm{FeSO}_{4} \cdot 7 \mathrm{H}_{2} \mathrm{O}, 1.0 \mathrm{~g} \mathrm{~K}_{2} \mathrm{HPO}_{4}$ and $12 \mathrm{~g}$ agar in 11 distilled water (Locci, 1989). Utilization of 
organic acids was tested by using the medium and method of Gordon et al. (1974). Gelatin liquefaction, skimmed milk peptonization, nitrate reduction and cellulose degradation were determined as described by Miyadoh (2001). Growth temperature and $\mathrm{NaCl}$ tolerances were determined on ISP 2. Melanin pigment formation was examined on tyrosine agar (ISP 7). The presence of isomers of diaminopimelic acid $\left(\mathrm{A}_{2} \mathrm{pm}\right)$ in the cell-wall hydrolysate was detected according to the methods described by Hasegawa et al. (1983). Samples for analysis of whole-cell sugars were prepared as described by Lechevalier \& Lechevalier (1970) and were analysed by the HPLC technique of Mikami \& Ishida (1983). Phospholipids were extracted according to the method of Minnikin et al. (1979) and identified using twodimensional TLC. Cellular fatty acid methyl esters were prepared and analysed according to the protocol of the MIDI Sherlock Microbial Identification System (Sasser, 1990; MIDI, 2002). Menaquinones were extracted by chloroform/methanol (2:1, v/v) (Minnikin et al., 1984) and analysed by LC/MS (LCMS QP8000 $\alpha$; Shimadzu). The acyl type of the muramic acid was determined by the method of Uchida \& Aida (1977). Mycolic acids were analysed by the method of Minnikin et al. (1975).

DNA was extracted by using a phenol/chloroform mixture and the method of Hopwood et al. (1985). RNA was removed following the method of Saito \& Miura (1963). The G+C content of the DNA was determined using the HPLC method of Tamaoka \& Komagata (1984). DNA-DNA relatedness was measured fluorometrically using the microplate hybridization method devised by Ezaki et al. (1989). The 16S rRNA gene was amplified using the PCR method with a Taq DNA polymerase and primers 9F (position 9-27, Escherichia coli numbering, Brosius et al., 1978) and 1541R (1541-1525). Amplification was performed using a DNA thermal cycler.
The amplified 16S rRNA gene fragment was purified and subjected directly to cycle sequencing using a BigDye Terminator v3.1 Cycle sequencing kit on an ABI3100 automated DNA sequencer (Applied Biosystems). The following primers were used for sequencing: 9F, 9-27; 785F, 785-805; 1541R, 1541-1525; 802R, 802-785 (Nakagawa et al., 2001).

The sequence was aligned with the selected sequences obtained from the GenBank/EMBL/DDBJ database by using the CLUSTAL_X program v.1.81 (Thompson et al., 1997). Alignments were manually verified and adjusted prior to the construction of a phylogenetic tree. The phylogenetic tree was constructed using the neighbourjoining method (Saitou \& Nei, 1987) in the MEGA3 program (Kumar et al., 2004). Distance matrices for the aligned sequences were calculated by the two-parameter method of Kimura (1980). The confidence values for branches of the phylogenetic tree were determined using bootstrap analyses (Felsenstein, 1985) based on 1000 resamplings.

Strain DMKUA $205^{\mathrm{T}}$ exhibited a range of phenotypic properties typical of members of the genus Herbidospora. The novel strain produced well-developed and nonfragmented branched substrate mycelia but true aerial mycelium was not formed. Straight, relatively short chains of non-motile spores were borne on the tips of long sporophores branching from the vegetative hyphae. The strain contained meso-diaminopimelic acid as the diagnostic diamino acid in the cell wall. Whole-cell hydrolysates contained glucose, mannose, ribose and madurose (3-0-methyl D-galactose) (cell-wall type IIIB of Lechevalier \& Lechevalier, 1970). Phosphatidylethanolamine, phosphatidylmethylethanolamine and glucosamine-containing phospholipids were detected. This result suggested that the phospholipid pattern was type PIV of Lechevalier $e t$ al. (1977). The fatty acid profiles contained $\mathrm{C}_{13: 0}(5.2 \%)$,

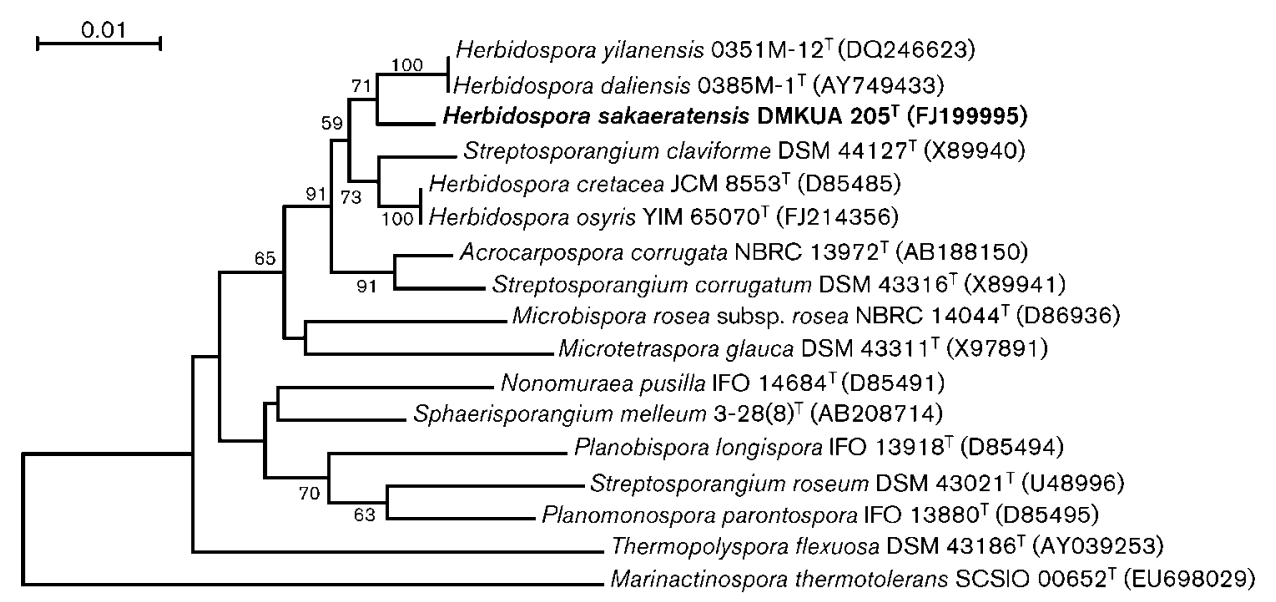

Fig. 1. 16S rRNA gene sequence-based neighbour-joining tree showing the relationship between strain DMKUA 205 ${ }^{\top}$, species of the genus Herbidospora and representatives of the family Streptosporangiaceae. Marinactinospora thermotolerans SCSIO $00652^{\top}$ (GenBank accession no. EU698029) was used as an outgroup. The numbers on the branches indicate the percentage bootstrap values of 1000 replicates (only values $>50 \%$ are indicated). Bar, 0.01 substitutions per nucleotide position. 
Table 1. Differential characteristics of strains DMKUA $205^{\top}, H$. yilanensis $0351 \mathrm{M}-12^{\top}$ and $H$. daliensis $0358 \mathrm{M}-1^{\top}$

Strains: 1 , DMKUA $205^{\mathrm{T}} ; 2$, H. yilanensis $0351 \mathrm{M}-12^{\mathrm{T}} ; 3, \mathrm{H}$. daliensis $0385 \mathrm{M}-1^{\mathrm{T}}$. All strains were positive for utilization of $\mathrm{D}$-fructose, D-galactose, D-glucose, D-mannitol and sucrose and for growth at $40{ }^{\circ} \mathrm{C}$. All strains were negative for cellulose degradation and for utilization of benzoic acid, dulcitol, mucic acid, D-ribose and D-sorbitol. +, Positive; -, negative; w, weak reaction.

\begin{tabular}{|lccc|}
\hline Characteristic & $\mathbf{1}$ & $\mathbf{2}$ & $\mathbf{3}$ \\
\hline Carbon utilization & & & \\
L-Arabinose & + & - & + \\
Maltose & - & + & + \\
Mannose & + & + & - \\
Melezitose & - & + & + \\
myo-Inositol & - & + & - \\
Raffinose & - & + & + \\
Rhamnose & - & + & + \\
Xylose & + & - & - \\
Organic acid utilization & & & \\
Fumaric & + & + & - \\
DL-Lactic & - & + & - \\
L-Malic & + & - & - \\
Succinic & + & + & - \\
NaCl tolerance $(\%, w / v)$ & 1.5 & 1 & 5 \\
\end{tabular}

i- $\mathrm{C}_{14: 0}(3.5 \%), \mathrm{C}_{15: 0}(29.1 \%), \mathrm{i}-\mathrm{C}_{16: 0}(17.4 \%), 2-\mathrm{OH}-$ $\mathrm{C}_{15: 0}(3.7 \%)$, cis9- $\mathrm{C}_{17: 1}(12.1 \%), \mathrm{i}-2-\mathrm{OH} \mathrm{C}_{16: 0}(4.3 \%)$, $\mathrm{C}_{17: 0}(8.2 \%)$ and 10-methyl $\mathrm{C}_{17: 0}(16.5 \%)$. Mycolic acids were absent. The major menaquinones were MK-10 $\left(\mathrm{H}_{4}\right)$ and MK-10 $\left(\mathrm{H}_{6}\right)$. The acyl type of the cell-wall muramic acid was acetyl. The $\mathrm{G}+\mathrm{C}$ content of the DNA was $73 \mathrm{~mol} \%$.

The phylogenetic tree (Fig. 1) showed that strain DMKUA $205^{\mathrm{T}}$ was phylogenetically closely related to $H$. yilanensis and $H$. daliensis. The $16 \mathrm{~S}$ rRNA gene sequence of strain DMKUA $205^{\mathrm{T}}$ shared $99 \%$ sequence similarity with $H$. yilanensis and $H$. daliensis. The physiological and biochemical characteristics of strain DMKUA $205^{\mathrm{T}}$ enabled the novel strain to be differentiated from the phylogenetically closest species $H$. yilanensis $0351 \mathrm{M}-12^{\mathrm{T}}$ and $H$. daliensis
0358 $-1^{\mathrm{T}}$ (Tseng et al., 2010; Table 1). Furthermore, DNA-DNA relatedness values in reciprocal hybridizations were much lower than $70 \%$ between strain DMKUA $205^{\mathrm{T}}$ and $H$. yilanensis $0351 \mathrm{M}-12^{\mathrm{T}}(35-54 \%$, reciprocal) and $H$. daliensis $0358 \mathrm{M}-1^{\mathrm{T}}(58-65 \%$, reciprocal), indicating that strain DMKUA $205^{\mathrm{T}}$ represents a separate genomic species (Table 2).

It is evident from the genotypic and phenotypic data that strain DMKUA $205^{\mathrm{T}}$ can be distinguished from previously described species of the genus Herbidospora. It is therefore proposed that this strain represents a novel species of the genus Herbidospora for which the name Herbidospora sakaeratensis sp. nov. is proposed.

DNA-DNA relatedness values in reciprocal hybridizations were $>70 \%$ between Streptosporangium claviforme and $H$. cretacea JCM $8553^{\mathrm{T}}$ (82.1 and $89.3 \%$, reciprocal), indicating that $S$. claviforme NBRC $15623^{\mathrm{T}}$ was indistinguishable from $H$. cretacea (Table 2). Therefore, the name $S$. claviforme should be treated as a later synonym of $H$. cretacea.

\section{Description of Herbidospora sakaeratensis sp. nov.}

Herbidospora sakaeratensis (sa.ka.e.ra.ten'sis. N.L. fem. adj. sakaeratensis pertaining to Sakaerat Biosphere Reserve, the source of the soil from which the type strain was isolated).

Aerobic, Gram-positive, mesophilic, non-motile actinomycete that forms non-fragmented branched vegetative hyphae, but true aerial mycelium is not formed. Spores are short rods and have smooth surfaces. Temperature range for growth is $20-40{ }^{\circ} \mathrm{C}$. Growth occurs between $\mathrm{pH} 6.0$ and 9.0. The maximum $\mathrm{NaCl}$ concentration for growth is $1.5 \%$ $(\mathrm{w} / \mathrm{v})$. Utilizes L-arabinose, D-fructose, D-galactose, D-glucose, D-mannitol, D-mannose, starch, sucrose and D-xylose as sole carbon sources, but not dulcitol, inositol, maltose, melezitose, raffinose, L-rhamnose, D-ribose or D-sorbitol. Utilizes fumaric acid, L-malic acid and succinic acid, but not benzoic acid or mucic acid. Tests for cellulose degradation, gelatin liquefaction, nitrate reduction, milk peptonization and melanoid pigment formation are negative. Cell walls contain meso-diaminopimelic acid as the diagnostic diamino

Table 2. Levels of DNA-DNA relatedness among strain DMKUA $205^{\top}$ and related taxa

Taxa: 1, DMKUA $205^{\mathrm{T}} ; 2$, H. yilanensis $0351 \mathrm{M}-12^{\mathrm{T}} ; 3$, H. daliensis $0385 \mathrm{M}-1^{\mathrm{T}} ; 4$, Streptosporangium claviforme $\mathrm{NBRC} 15623^{\mathrm{T}}$; 5 , H. cretacea JCM $8553^{\mathrm{T}}$. The data are mean \pm standard deviations from the mean. ND, not determined.

\begin{tabular}{|c|c|c|c|c|c|c|}
\hline \multirow[t]{2}{*}{ Strain } & \multirow[t]{2}{*}{ DNA G $+C$ content $(\mathrm{mol} \%)$} & \multicolumn{5}{|c|}{ \% DNA-DNA relatedness with labelled DNA from: } \\
\hline & & 1 & 2 & 3 & 4 & 5 \\
\hline 2. $0351 \mathrm{M}-12^{\mathrm{T}}$ & 70.6 & $54.0 \pm 13.4$ & 100 & $53.6 \pm 0.9$ & ND & ND \\
\hline 3. $0385 \mathrm{M}-1^{\mathrm{T}}$ & 70.7 & $65.0 \pm 4.9$ & $54.9 \pm 0.9$ & 100 & ND & ND \\
\hline 4. NBRC $15623^{\mathrm{T}}$ & ND & $47.4 \pm 2.6$ & $\mathrm{ND}$ & ND & 100 & $82.1 \pm 5.0$ \\
\hline
\end{tabular}


acid and $\mathrm{N}$-acetylated muramic acid. Whole-cell hydrolysates contain madurose (chemotype IIIB). The phospholipid profile contains phosphatidylethanolamine, phosphatidylmethylethanolamine and glucosamine-containing phospholipids (phospholipid type PIV). The major cellular fatty acids are $\mathrm{C}_{17: 1} \omega 9 c, 10$-methyl $\mathrm{C}_{17: 0}$, iso- $\mathrm{C}_{16: 0}$ and $\mathrm{C}_{15: 0}$ (fatty acid type $3 \mathrm{c}$ ). Mycolic acids are absent. The predominant menaquinones are MK-10 $\left(\mathrm{H}_{4}\right)$ and $\mathrm{MK}-10\left(\mathrm{H}_{6}\right)$.

The type strain, DMKUA $205^{\mathrm{T}} \quad\left(=\mathrm{BCC} \quad 11662^{\mathrm{T}}=\right.$ NBRC $102641^{\mathrm{T}}$ ), was isolated from soil. The DNA G $+\mathrm{C}$ content of the type strain is $73 \mathrm{~mol} \%$.

\section{Acknowledgements}

The scholarship from the Royal Golden Jubilee PhD Program is gratefully acknowledged. This work was carried out under the collaboration of the Core University Program between Yamaguchi University, Khonkaen University and Kasetsart University, supported by the International Cooperation Project 'Thai-Japan Academic Cooperation Project' with the support of the NRCT and JSPS, Asian Core Program. A part of this research was funded by the Center for Advanced Studies in Tropical Natural Resources, Institute for Advanced Studies and Graduate School, Kasetsart University.

\section{References}

Brosius, J., Palmer, M. L., Kennedy, P. J. \& Noller, H. F. (1978). Complete nucleotide sequence of a $16 \mathrm{~S}$ ribosomal RNA gene from Escherichia coli. Proc Natl Acad Sci U S A 75, 4801-4805.

Ezaki, T., Hashimoto, Y. \& Yabuuchi, E. (1989). Fluorometric deoxyribonucleic acid-deoxyribonucleic acid hybridization in microdilution wells as an alternative to membrane filter hybridization in which radioisotopes are used to determine genetic relatedness among bacterial strains. Int J Syst Bacteriol 39, 224-229.

Felsenstein, J. (1985). Confidence limits on phylogenies: an approach using the bootstrap. Evolution 39, 783-791.

Gordon, R. E., Barnett, D. A., Handerhan, J. E. \& Pang, C. H.-N. (1974). Nocardia coeliaca, Nocardia autotrophica, and the Nocardin strain. Int J Syst Bacteriol 24, 54-63.

Hasegawa, T., Takizaea, M. \& Tanida, S. (1983). A rapid analysis for chemical grouping aerobic actinomycetes. J Gen Appl Microbiol 29, 319-322.

Hayakawa, M. \& Nonomura, H. (1987). Humic acid-vitamin agar, a new medium for the selective isolation of soil actinomycetes. J Ferment Technol 65, 501-509.

Hopwood, D. A., Bibb, M. J., Chater, K. F., Kieser, T., Bruton, C. J., Kieser, H. M., Lydiate, D. J., Smith, C. P. \& Ward, J. M. (1985). Preparation of chromosomal, plasmid and phage DNA. In Genetic Manipulation of Streptomyces - a Laboratory Manual, pp. 79-80. Edited by D. A. Hopwood, M. J. Bibb, K. F. Chater, H. M. Kieser, D. J. Lydiate, C. P. Smith, J. M. Ward \& H. Schrempf. Norwich: John Innes Foundation.

Kimura, M. (1980). A simple method for estimating evolutionary rates of base substitutions through comparative studies of nucleotide sequences. J Mol Evol 16, 111-120.

Kudo, T., Itoh, T., Miyadoh, S., Shomura, T. \& Seino, A. (1993). Herbidospora gen. nov., a new genus of the family Streptosporangiaceae Goodfellow et al. 1990. Int J Syst Bacteriol 43, 319-328.
Kumar, S., Tamura, K. \& Nei, M. (2004). MEGA3: Integrated software for molecular evolutionary genetics analysis and sequence alignment. Brief Bioinform 5, 150-163.

Lechevalier, M. P. \& Lechevalier, H. A. (1970). Chemical composition as a criterion in the classification of aerobic actinomycetes. Int $J$ Syst Bacteriol 20, 435-443.

Lechevalier, M. P., DeBievre, C. \& Lechevalier, H. A. (1977). Chemotaxonomy of aerobic actinomycetes: phospholipid composition. Biochem Syst Ecol 5, 249-260.

Locci, R. (1989). Streptomycetes and related genera. In Bergey's Manual of Systematic Bacteriology, vol. 4, pp. 2463-2464. Edited by S. T. Williams, M. E. Sharpe \& J. G. Holt. Baltimore: Williams \& Wilkins.

MIDI (2002). MIS operating manual, version 4.5. Newark, Delaware: MIDI, Inc.

Mikami, H. \& Ishida, Y. (1983). Post-column fluorometric detection of reducing sugars in high-performance liquid chromatography using arginine. Bunseki Kagaku 32, E207-E210.

Minnikin, D. E., Alshamaony, L. \& Goodfellow, M. (1975). Differentiation of Mycobacterium, Nocardia, and related taxa by thin-layer chromatographic analysis of whole-organism methanolysates. J Gen Microbiol 88, 200-204.

Minnikin, D. E., Collins, M. D. \& Goodfellow, M. (1979). Fatty acid and polar lipid composition in the classification of Cellulomonas, Oerskovia and related taxa. J Appl Bacteriol 47, 87-95.

Minnikin, D. E., O’Donnell, A. G., Goodfellow, M., Alderson, G., Athalye, M., Schaal, A. \& Parlett, J. H. (1984). An integrated procedure for the extraction of bacterial isoprenoid quinones and polar lipids. J Microbiol Methods 2, 233-241.

Miyadoh, M. (2001). Gene analysis method. In Identification Manual of Actinomycetes, pp. 9-19. Edited by S. Miyadoh, M. Hamada, K. Hotta, T. Kudo, A. Seino, K. Suzuki \& A. Yokota. Japan: Business Center for Academic Societies Japan.

Nakagawa, Y., Tamura, T. \& Kawasaki, H. (2001). Gene analysis method. In Identification Manual of Actinomycetes, pp. 83-117. Edited by S. Miyadoh, M. Hamada, K. Hotta, T. Kudo, A. Seino, K. Suzuki \& A. Yokota. Japan: Business Center for Academic Societies Japan.

Saito, H. \& Miura, K. I. (1963). Preparation of transforming deoxyribonucleic acid by phenol treatment. Biochim Biophys Acta 72, 619-629.

Saitou, N. \& Nei, M. (1987). The neighbor-joining method: a new method for reconstructing phylogenetic trees. Mol Biol Evol 4, 406425.

Sasser, M. (1990). Identification of bacteria by gas chromatography of cellular fatty acids. Newark, Delaware: Microbial ID, Inc.

Shirling, E. B. \& Gottlieb, D. (1966). Methods for characterization of Streptomyces species. Int J Syst Bacteriol 16, 313-340.

Tamaoka, J. \& Komagata, K. (1984). Determination of DNA base composition by reversed-phase high-performance liquid chromatography. FEMS Microbiol Lett 25, 125-128.

Thompson, J. D., Gibson, T. J., Plewniak, F., Jeanmougin, F. \& Higgins, D. G. (1997). The CLUSTAL_X windows interface: flexible strategies for multiple sequence alignment aided by quality analysis tools. Nucleic Acids Res 25, 4876-4882.

Tseng, M., Yang, S.-F. \& Yuan, G.-F. (2010). Herbidospora yilanensis sp. nov. and Herbidospora daliensis sp. nov., from sediment. Int J Syst Evol Microbiol 60, 1168-1172.

Uchida, K. \& Aida, K. (1977). Acyl type of bacterial cell wall: its simple identification by a colorimetric method. J Gen Appl Microbiol 23, 249-260. 